\author{
УДК 328.184:316.344.42(73) \\ https://doi.org/10.34142/24130060.2019.17.1.05
}

\title{
ВПЛИВ ЛОБІЗМУ НА ФОРМУВАННЯ ПОЛІТИЧНОЇ ЕЛІТИ США
}

\begin{abstract}
А.В. Горбачов
Харківський національний педагогічний університет імені Г.С. Сковороди

У статті розглядається вплив лобізму на формування політичної еліти США. Проводиться історичний та правовий аналіз становлення лобістської діяльності в США. Визначаються сочіально-економічні фактори, які сприяли трансформації політичних стосунків в суспільстві та дифузії елементів ринку в політичну систему. Досліджений процес становлення нового типу еліт в США, які використовують своє матеріальне положення та лобіювання для контролю політичних процесів в країні.
\end{abstract}

Ключові слова: політична еліта, ринок політичних послуг, політична система, лобіювання.

\section{ВЛИЯНИЕ ЛОББИЗМА НА ФОРМИРОВАНИЕ ПОЛИТИЧЕСКОЙ ЭЛИТЫ США}

\begin{abstract}
А.В. Горбачев
В статье рассматриваются влияние лоббизма на формирование политической элиты США. Проводится исторический и правовой анализ становления лоббистской деятельности в США. Определяется социально-экономические факторы, которые способствовали трансформаџии политических отношений в обществе и способствовали встраиванию элементов рынка в политическую систему. Исследован процесс становления нового типа элит в США, которые используют свое материальное положение и лоббирование для контроля политических прочессов.

Ключевые слова: политическая элита, рынок политических услуг, политическая система, лоббирование.

\section{INFLUENCE OF LOBBYING ON THE FORMATION OF THE US POLITICAL ELITE}

\section{A. Horbachov}

The article examines the impact of lobbying on the formation of the US political elite. The author conducts a historical and legal analysis of the formation of lobbying activity in the USA. The socio-economic factors contributing to the transformation of political relations in the society and the establishment of market elements in the political system are determined. An impact of lobbying on the formation of political elite was defined through the example of the US political system. The author discovers the emergence of a new type of elite in the United States, which uses their material position and lobbying to control political processes.

Lobbying is now one of the most important components of modern Western politics. The role of lobbying and the associated influence of interest groups on state power is constantly increasing. Many researchers consider this process as the greatest threat to the legitimacy of democracy. In general, the dependence of the work of legislators and officials on the influence of
\end{abstract}

(C) A.В. Горбачов, 2019 
interest groups (first of all, big business), which leads to activity of lobbyists, remains a very urgent problem for the scientific community and practitioners of political activity. It adds to the weakening of the influence of the traditional left-wing forces in the face of trade unions, which is typical for the modern political environment. Left-wing forces are more likely to expose the influence of lobbying on politics, rather than effectively resist this phenomenon. On the contrary, on the right side, politicians evaluate and perceive lobbying more positively. Under these conditions, lobbying forms new political elite in the socio-political sphere today.

M. Adams, A. Bentley, B. Wool, J. Habermas, R. Dahl, M. Duverger, C. Andrew, D. Epert, A. Leipgart, M. Olson, R. Price, D. Truman, F. Schmitter, F. Stolz, J. Schumpeter and other researchers, dealt with the analysis of this problem.

The article notes that lobbyism at the very beginning of its formation is seamlessly integrated into the US political system as an element of the market, and the danger of such a process was emphasized. J. Schumpeter pointed out that the main threat to capitalist market relations subject to crisis was not the economic side of the crisis such as low growth rates, inefficiency, high unemployment. All this could be overcome within the framework of the capitalist system. Other social institutions such as family, education system, etc., could be subject to crises.

Keywords: political elite, market of political services, political system, lobbying.

Постановка проблеми. Лобізм в даний час $€$ однією 3 найбільш важливих складових сучасної західної політики. Роль лобізму і пов'язаного 3 ним впливу груп інтересів на державну владу збільшується. Багато дослідників розглядають цей процес як найбільшу загрозу легітимності демократії. В цілому залежність роботи законодавців і посадових осіб від впливу груп інтересів (перш за все, великого бізнесу), яку створює діяльність лобістів, залишається актуальною проблемою для наукової спільноти та практиків політичної діяльності. Додаткову гостроту їй додає ослаблення впливу традиційних лівих сил в особі профспілок, що є характерним для сучасного політичного середовища. Ліві швидше викривають вплив лобізму на політику, ніж дієво чинять опір цьому явищу. Навпаки, на правому фланзі політики, під впливом неоконсерваторів, явище лобізму оцінюється i сприймається багато в чому по-іншому, більш позитивно. В таких умовах в суспільно-політичній сфері формуються нові політичні еліти США.

Аналіз актуальних досліджень. Аналізом даної проблеми займалися
М. Адамс,
А. Бентлі,
Б. Вулп,
Ю. Габермас,
Р. Даль,
М. Дюверже,
Ч. Ендрейн, Д. Ептер,
А. Лейпгарт, М. Олсон,
Р. Прайс,
Д. Трумен,
Ф. Шміттер, Ф. Штольц, Й. Шумпетер та інші дослідники. 
Більшість дослідників робили наголос на подвійній природі представництва лобістських груп - лобіювання ураховує інтереси як i населення, так і бізнес-лобі. Ще одна проблема, на якій концентрується увага вчених, - діяльність лобізму на межі підприємницької та політичної діяльності. Лобізм в працях науковців пов'язаний з такими явищами, як вплив на законодавчу та виконавчу владу, організаційне сприяння діяльності соціальних груп (громадських об'єднань, профспілок та ін.), формування іміджу груп інтересів для влади та суспільства, використання політичних комунікацій та мас-медіа, конкуренція з іншими групами та політичними організаціями.

Умовно ми можемо розділити дослідження на декілька наукових секторів. Теорії груп (А. Бентлі, Д. Трумен, М. Дюверже та ін.) розглядають лобіювання як засіб, який застосовують окремі групи для контролю політичного поля держави. Теорія плюралістичної демократії (Р. Даль, А. Лейпгартта ін.) розглядає лобістську діяльність як можливість не представленим у владі соціальним групам впливати на законодавчий процес. Теорії політичної конкуренції, політичної комунікації, політичних мереж та ринків (Ф. Шміттер, Ф. Штольц, Й. Шумпетер, Ю. Габермас та ін.) розглядають інструменти лобіювання, які $є$ характерними для сучасного політикума. Але мало досліджуваним $є$ визначення ролі лобізму як інструменту створення політичних еліт.

Мета статті - аналіз впливу лобізму на формування політичної еліти США.

Виклад основного матеріалу. Лобізм в політологічному дискурсі розглядається як діяльність окремих осіб або груп, яка спрямована на діяльність органів державної влади 3 метою вплинути на прийняття i здійснення зазначеними органами законодавчих актів і адміністративних рішень. Існує багато інших визначень лобізму: В. Рудзіо тлумачить лобіювання як діяльність лобістів у парламенті, які намагаються здійснити вплив на законодавців 3 метою відстояти вигідний певним групам 
законопроект. Ф. Ж. Фарнель $(1994$, с. 16) визначає лобіювання як діяльність, спрямовану на створення прямого або непрямого впливу на законодавчий або нормативний процес й т. ін. Однак смислове наповнення цього поняття залишається незмінним: лобізм - це будь-які дії, спрямовані на отримання потрібних від державної влади рішень.

Слова «лобіювання» та «лобіст», вперше набули політичного сенсу в США завдяки У.С.Гранту, генералу, який здобув славу в період Громадянської війни 1861-1865 рр. і президенту країни в 1869-877 рр. Він мав звичку проводити вечори в лобі - вестибюлі готелю «Віллард» у Вашингтоні, округ Колумбія, де кожен бажаючий міг звернутися до нього 3 проханням про сприяння у вирішенні тієї чи іншої проблеми. Такі прохання часто підкріплювалися грошима. Грант називав таких прохачів «лобістами». Згодом лобіюванням в США стала називатися практика купівлі голосів виборців. Тому значною мірою сприяла відсутність відповідного законодавства. Більшість реформ лобіювання в США було проведено під тиском громадськості. Наприклад, сумнівна діяльність лобістів, що представляли інтереси компаній, що брали участь в будівництві залізниці у 1861-1865 рр., заснувала сучасну практику правового регулювання вартості такого будівництва в Америці. Ще в 1852 р. Палата представників США приймає резолюцію, згідно 3 якою в приміщення законодавчого органу забороняється пускати тих, кого найняли в якості лобіста для вирішення будь-якої проблеми через Конгрес. У 1854 р. в Конгресі США створюється спеціальний комітет для з’ясування участі лобістських організацій у впливі на прийняття певних законодавчих актів. У 1876 р. Палатою представників приймається ще одна резолюція, згідно з якою лобістські організації повинні повідомляти про свою діяльність у спеціальний комітет (Eskridge, 2009, p. 6). 3 цього історичного екскурсу можна побачити, що лобізм вже на початку свого становлення плавно вбудовується в політичну систему США як елемент ринку. Свого часу Й. Шумпетер (1995) визначив соціальну небезпеку подібного процесу. Він вказував, що головною загрозою 
капіталізму $\epsilon$ не економічна сторона кризи: низькі темпи зростання, неефективність, високе безробіття - все це можливо подолати в рамках капіталістичної системи. Жертвами кризи стають інші соціальні інститути: сім'я, система освіти і т. ін. Механізмом активного впровадження елементів ринкової економіки в соціальні інститути стає так звана «раціоналізація». Основним двигуном цих трансформацій є великі концерни - акціонерні товариства і великі компанії. Таким чином, розвиток капіталізму повсюдно сприяє дифузії ринкових відносин у функціонування політичних інститутів. При капіталізмі політика як би стає галуззю економіки, в якій діють закони конкуренції: люди, які бажають отримати політичну владу, вступають між собою в конкурентну боротьбу за голоси виборців. Ця точка зору Шумпетера потім підтвердилась на протязі XX століття.

Починаючи з середини XX століття в Європі та США починаються економічні та соціально-політичні перетворення. Ці перетворення також змінили й саму систему лобіювання, зробивши ії більш схожою на ринкову структуру, а не на державну. На їі зміну вплинуло декілька факторів:

1. Відхід від кейнсіанської економічної моделі розвитку економіки й формування ліберальної економічної моделі. Кейнсіанська модель розвитку економіки стала основою економічної політики індустріально розвинених держав, починаючи з середини 30-х років. Вона грала найважливішу роль в трансформації капіталістичної системи економіки, в якій державне врегулювання ефективним чином взаємодіє 3 ринковими механізмами. Ліберальна модель економіки, яка прийшла на зміну кейнсіанській, була реакцією на державне втручання у вирішення питань економічного характеру. Ліберали спрямовувалися до вільної конкуренції всередині держави i торгової свободи між різними державами. На їхню думку, індивідуалізоване підприємництво, яке діє на ринку відповідно до принципу конкуренції, представляється прямим відображенням фундаментальних свобод в економічному середовищі і джерелом свободи в політичній сфері (Palley, 2004). 
2. Становлення 3МІ як нового джерела політичної соціалізації. 3 середини XX століття 3МI стали новим джерелом політичної агітації. При чому така агітація стає схожою на привабливе ток-шоу. А на зміну партійній роботі з виборцями прийшли політтехнологи, що розглядають політичні сили як товар, який потрібно продати.

3. Побудова партій на основі спекулювання та театралізації дій. До середини XX століття партії формувались на основі представництва - участь в партії приймали представники різних прошарків суспільства для своєчасного реагування на проблеми в державі. Але з розвитком телебачення і ЗМІ партї̈ почали активно використовувати піар та телебачення для агітації. За таких умов лобіювання стає новою автономною системою, яка була в повній мірі адаптована до нових умов XX століття, - цей інститут став основним посередником між соціальними групами та державою, забираючи цю функцію у партій, які стають лише «топ-менеджерами» в політичній системі. Лобіювання впровадило можливість вирішення політичних проблем ринковими засобами - заплати за те, щоб твою проблему почули. В результаті цих змін більшість груп інтересів почали звертатися до лобістських організацій по допомогу в законодавчому закріпленні своїх вимог. Але лобісти не тільки звертаються з проханням до органів виконавчої влади, а пропонують свої варіанти законопроектів (Біллів) 3 потрібних питань. Зрозуміло, на стадії висування законодавчих ініціатив справа не закінчується: лобісти здійснюють цілеспрямований політичний «супровід» на всіх фазах проходження білля крізь органи виконавчої влади. У такий спосіб при належній цілеспрямованості та необхідній кількості матеріальних ресурсів можна поступово перебудувати значну частину нормативноправової бази держави, сформувати коло політичних діячів, що відповідали б вимогам великого бізнесу.

Поширення лобізму в політичну практику та посилення його впливу на процес формування політичної еліти досить наочно можна побачити на прикладі США. Аналіз наукових статей початку XXI століття на дану 
тематику свідчить про те, що процес переходу лобіювання до стану основоположного чинника політичної системи здійснився. Під його впливом змінилася сама виборча система, були сформовані вимоги до сучасної політичної еліти, визначилося коло людей, зацікавлених в просуванні тих чи інших законопроектів. Аналізуючи політичну систему США, можна зробити висновок, що нинішня політична система країни приносить користь, перш за все, діючим членам конгресу і членам інших державних органів. Державні чиновники і конгресмени отримують вигоду від своїх посад і встановлених ділових зв'язків, які вони використовують для фінансування та проведення своїх виборчих кампаній. Вони стають «штатними співробітниками» в такій системі, що фінансуються в повному обсязі як державою, так і інвесторами, при цьому виконують роботу для трьох соціальних груп: виборців, вищих чинів i інвесторів. У той же час дійові особи надають претендентам (індивідам, які до цього не були частиною політичної системи) доступ до безкоштовних теле- та радіостудій, дозволяють користуватися безкоштовною поштовою доставкою і федеральними субсидованими інтернет-сайтами. Ці привілеї є цілком легальною частиною виборчої кампанії. Проте, прірва між діючими особами і претендентами, які мають однаковий грошовий капітал, $є$ величезною. Закон надто сприяє чинним посадовцям. Державне фінансування надає обов'язковий капітал, який може допомогти претендентам запустити виборчі кампанії i залучити додаткові пожертвування, але тоді встановлюються жорсткі рамки бюджету. Що ж стосується виборчої кампанії в Конгрес, то на нього обов'язкове державне фінансування не поширюється - претендент має право не приймати державну допомогу, але тоді бюджет його виборчої кампанії фактично необмежений. 3 урахуванням вкладу в громадську діяльність багато інвесторів тепер вважають за доцільне давати гроші тільки дійовим особам. Дійові особи, в свою чергу, використовують відкриту інформацію та 3МI для перешкоджання потенційним претендентам, звинувачуючи їх в особистій зацікавленості і корупції. Хоча «інвестиції» не купують голоси законодавців, 
вони купують можливість вирішити свої питання за допомогою дійових осіб. У такий спосіб в умовах «визначеності» політичних ролей в політичній системі починається формування нової політичної еліти США.

Особливе значення в формуванні нового типу еліт в США зіграло лобіювання, яке дало поштовх для його появи. Базисом такої еліти $є$ представники великого бізнесу, які утримують в своїх руках основні важелі впливу на економіку. Ці еліти не однорідні і поділяються в залежності від сфери інтересів, характеру діяльності на групи бізнес-лобі. Бізнес-лобі - це сукупність великих підприємницьких асоціацій, що борються за певні інтереси. Такі асоціації можуть бути постійними, а можуть створюватися на короткий термін для вирішення нагальних проблем. При цьому можливі коаліції таких організацій або їх взаємне протистояння. Приєднання до таких асоціацій і вихід з них, як правило, вільний: головне - це активна підтримка діяльності асоціації. У цих групах можливі зміни позицій окремих компаній, але список проблем, з якими мають справу лобісти, залишається незмінним. Умови, в яких існує сучасний лобізм, так само мінливі і хаотичні, як і самі група інтересів. Політичне життя формується у вигляді об'ємного ринку: політичне поле - це місце, де в конкурентній боротьбі між представниками різних груп політичної еліти народжується політична продукція: проблеми, програми, аналізи, коментарі, концепції, події, з яких і повинні вибирати звичайні громадяни. Всі ці продукти сформовані таким чином, що вони виглядають товаром, готовим для споживання індивідами. Політичні еліти формують політичну систему на зразок ринкової системи, де політичний «товар» дістається електорату, а важелі впливу на політику - бізнес-лобі.

Висновки і перспективи подальших досліджень. Таким чином, лобізм в США сьогодні дієво формує політичну еліту в демократичному суспільстві, забезпечуючи необхідний для прийняття законів приплив інформації, дозволяючи законодавцям оцінити комплекс існуючих інтересів громадськості та ступінь підтримки тих чи інших законопроектів представниками різних соціальних груп. А з іншої сторони, лобізм є дійовим 
лише за умов дифузії ринкових відносин в політичні процеси, що робить його інструментом панування окремих груп політичного впливу. В результаті лише політичні еліти мають змогу формувати нормативно-правову й економічну систему в суспільстві. В подальшому слід дослідити вплив лобізму на структуру суспільства загалом для більш глибокого розуміння суспільно-політичних процесів в США.

\section{ЛІТЕРАТУРА}

1. Фарнель, Ф.Ж. 1994. Лоббирование: Стратегии и техники вмешательства. Париж: Les Editions D‘Organisation.

2. Шумпетер, Й. 1995. Капитализм, социализм и демократия. Москва: Экономика.

3. Johnston, M. 2005. Syndromes of Corruption: Wealth, Power, and Democracy. NewYork: Cambridge University Press.

4. Oritz, J., 2003. Linking Public Interest, Trustand Value Topic: Building Credibility and Trust through Public Involvement. The American Society for Public Administration, 26(7), p.165-180.

5. Palley, I.T., 2004. From Keynesianism to Neoliberalism: Shifting Paradigms in Economics. Foreign Policyin Focus. [online] (Last updated 5 May 2004) Available at: http://fpif.org/from_keynesianism_to_neoliberalism_shifting_paradigms_in_economics/ [Accessed 11 Desember 2018].

6. Eskridge, W. N., 2009. Federal Lobbying Regulation: HistoryThrough 1954. In: W. V. Luneburg, T. M. Susman and R.H. Gordon, ed. 2009. The Lobbying Manual: a complete guide to federal lobbying law and practice. American Bar Association. 4-th. ed.

7. Simpson, D. and Ulysses, S. 2000. Grant: Triumph over Adversity, 1822-1865. NewYork : Houghton Mifflin.

\section{Інформація про автора}

Горбачов Антон Володимирович - аспірант кафедри політології, соціології і культурології Харківського національного педагогічного університету ім. Г.С. Сковороди; e-mail: gorbachovav2302@gmail.com; ORCID: https://orcid.org/0000-0003-4503-7547.

Стаття надійшла до редакції: 05.012019 р. $\quad$ Прийнята до друку: 24.01.2019 p. 